Abstracta Iranicacta Iranica

Revue bibliographique pour le domaine irano-aryen

Volume 34-35-36 | 2017

Comptes rendus des publications de 2011-2013

\title{
Kourosh Roustaei. Archaeological survey of the Šāhrud area, Northeast Iran: A landscape approach
}

\section{Rémy Boucharlat}

\section{(2) OpenEdition}

10 Journals

Édition électronique

URL : http://journals.openedition.org/abstractairanica/41803

DOI : 10.4000/abstractairanica.41803

ISSN : 1961-960X

\section{Éditeur :}

CNRS (UMR 7528 Mondes iraniens et indiens), Éditions de l'IFRI

\section{Référence électronique}

Rémy Boucharlat, « Kourosh Roustaei. Archaeological survey of the Šāhrud area, Northeast Iran: A landscape approach ", Abstracta Iranica [En ligne], Volume 34-35-36 | 2017, document 18, mis en ligne le 30 décembre 2016, consulté le 03 octobre 2020. URL : http://journals.openedition.org/ abstractairanica/41803; DOI : https://doi.org/10.4000/abstractairanica.41803

Ce document a été généré automatiquement le 3 octobre 2020.

Tous droits réservés 


\title{
Kourosh Roustaei. Archaeological survey of the Šährud area, Northeast Iran: A landscape approach
}

\author{
Rémy Boucharlat
}

\section{RÉFÉRENCE}

Kourosh Roustaei. « Archaeological survey of the Šāhrud area, Northeast Iran: A landscape approach ». AMIT 44, 2012, p. 191-219.

1 La zone prospectée est l'étroit corridor est-ouest constitué du piémont du versant sud de l'Alborz jusqu'au bord de la dépression du désert salé dans lequel se perdent les cours d'eau. Elle reçoit moins de $200 \mathrm{~mm}$ de précipitations par an. Au cours de l'occupation entre le Néolithique acéramique (VII ${ }^{\mathrm{e}}$ mill.) et l'époque islamique, se produit un changement : les zones sont longtemps localisées sur le bas des cônes alluviaux, là où l'eau était disponible dans les wādīs ou par des puits. À partir de l'époque achéménide, mais plus nettement aux époques parthe et sassanide, l'occupation se déplace vers aval, loin de l'extrémité des wādīs, dans une zone aux terres plus favorables à l'agriculture (voir les cartes). Selon l'A., cette nouvelle implantation est rendue possible par l'irrigation par qanāt. À l'époque islamique, les sites sont beaucoup plus nombreux et la relation de plusieurs d'entre eux avec un qanāt est avérée. Une pièce à verser au dossier de l'histoire et de la datation, encore très controversée, des débuts cette technique hydraulique emblématique de l'Iran. 


\section{AUTEURS}

RÉMY BOUCHARLAT

CNRS, Lyon 